\title{
Engagement Strategy for a Racism-Free Workplace
}

\author{
John Samuel and Nand Tandon \\ John Samuel and Associates, Ottawa \\ johntsamuel@rogers.com
}

\section{Executive Summary}

The Engagement Plan for a Racism-Free Workplace forms part of the Labour Program of [the federal government's] HRSDC's drive to end race-based discrimination in the workplace faced by Aboriginal peoples and members of visible minority groups. As well, the federal government has made a commitment to removing race-related barriers in the workplace and to consulting racial and ethnic groups in developing public policy to achieve this objective.

The focus for this strategy is employers covered by the expanded mandate of the Employment Equity Act (EEA), which includes employers under the Federal Contractors Program (FCP), as well as those covered under the Legislative Employment Equity Program (LEEP). The stakeholders whose views will inform this project are people who have an interest or relationship with the FCP or LEEP [such employers include]: trade unions, voluntary organizations and other members of the civil society ${ }^{1}$ interested in promoting a racism-free workplace.

Canada is expected to become increasingly dependent on immigrants and hitherto underutilized labour force members, like Aboriginal peoples, to meet the labour market demands of an increasingly globalized world. The contributions of Canada's historical sources of immigration the European countries - have begun to diminish. Asia, Africa and the Latin American countries have begun accounting for a rising number of new Canadians. A number of Statistics Canada studies point to major increases in the number of visible minorities and Aboriginal peoples in the next six or seven years. Yet, visible minorities and Aboriginal peoples face barriers in the labour market and poorer employment outcomes. This is attributed to a number of other factors, including race-based discrimination. Canada cannot simply coast on the status quo if we want to remain competitive in a global economy.

The EEA is expected to come up for examination in the current Parliament [2015]. This makes it an appropriate time to seek public input on amendments to the act. The current Plan, a project that is consultative, educational and aimed at developing a racism-free workplace, is timely.

\section{Objectives and Methodology}

The project objectives were to identify views about racism in the workplace by consulting stakeholder groups and individuals. As well, workplace practices and policies were looked at to see how they affected Aboriginal peoples and members of visible minority groups in their entry, retention and advancement at work. Participants were also asked to propose countermeasures to eliminate workplace barriers based on race. Partnership sessions were held to elicit from

\footnotetext{
${ }^{1}$ The term "the civil society" encompasses voluntary associations of Aboriginal peoples and members of visible minority groups, immigrant aid organizations, academics, employment equity practitioners and other professionals with an interest in a race-free workplace.
}

Cultural and Pedagogical Inquiry, Fall 2020, 12(2), pp. 165-171

ISSN 1916-3460 @ 2020 University of Alberta

http://ejournals.library.ualberta.ca/index.php/cpi/index 
stakeholders ways to develop long-term, sustainable partnerships among those who will work on race-based discrimination in the workplace. Finally, the project team provided training and tools to stakeholders to address various aspects of race-based workplace discrimination.

To meet these objectives, a series of activities were held in eight metropolitan centres across Canada: Vancouver, Calgary, Regina, Winnipeg, Toronto, Ottawa, Montreal and Halifax. Twoday sessions were held in each city, except Regina, where the sessions were restricted to a single day. ${ }^{2}$ From a master stakeholder list of over 5,000 names in various categories, invitees were asked to attend meetings in one of the cities in February and early March. This resulted in about 800 participants attending 39 focus groups, 31 workshops and 28 partnership sessions across the country.

The focus group consultations were the major source of information on the barriers faced by Aboriginal peoples and members of visible minority groups in the workplace. These sessions were also used to elicit stakeholders' ideas for solutions to remove the barriers. The workshop sessions, on the other hand, were designed to educate participants about topics relating to the implementation of employment equity programs. Using questionnaires and other methods of drawing people out, the groups worked on case studies of racial discrimination under the guidance of the moderators. Current workplace practices and procedures were examined with a view to finding ways to remove workplace barriers. The sessions on partnerships were used to lay the groundwork for creating sustainable partnerships of stakeholders in each region.

\section{The Focus Group Consultations}

For the purposes of this report, the findings from the focus group discussions are broken down under three titles: (i) entering the workplace, (ii) workplace retention and (iii) career advancement. Regional variations are also discussed, along with the benefits of establishing a racism-free workplace.

Commonalties were discovered between recent visible minority immigrants and Aboriginal people, particularly young people, moving off reserves to urban centres. Both faced the barriers of being confronted by a new culture and language, the need to find housing, the lack of their customary community and family supports and a lack of awareness of available employment.

Participants in all focus group consultations repeatedly mentioned hidden and overt racism as being a factor in the workplace. For example, people talked about the unofficial screening of résumés that can take place based on foreign-sounding names. Other participants mentioned that visible minorities are often considered over-qualified for jobs they apply for, while Aboriginal people are considered under-qualified. Some participants believed this could be a pretext to get them out of the competition.

Barriers against Aboriginal peoples in today's economy were seen as being somewhat the same as they've been for many years: negative stereotyping of them as "uneducated, lazy, drunk, untrustworthy and unskilled". Lack of education and appropriate training were often-cited barriers, as well. A participant spoke about the chronic under-funding and poor quality of education on reserves. On the other hand, another participant stated that there are currently some

\footnotetext{
${ }^{2}$ Consultations were conducted in a focus group format.

Cultural and Pedagogical Inquiry, Fall 2020, 12(2), pp. 165-171

ISSN 1916-3460 @ 2020 University of Alberta

http://ejournals.library.ualberta.ca/index.php/cpi/index
} 
60,000 Aboriginal students in universities. Although the last residential school was closed in the 1980s, some participants said the scars on a generation of children are now causing lack of selfesteem and other difficulties that also act as barriers to finding work.

The greatest barrier for visible minorities getting into the workplace was seen to be the nonrecognition of immigrants' qualifications and the absence of adequate learning assessments. This was talked about often right across the country. It appeared most acute in Toronto and Montreal. Language was another difficulty, particularly in Québec. The system of union hiring halls in some provinces was seen as barriers for visible minorities. Religious intolerance was mentioned as a barrier, particularly for Muslims. A recurring theme in the focus group consultations was the hierarchy of racism, with Blacks placed at the bottom of the ladder. Participants thought that refugees faced increased problems, given that many of them have faced great trauma in the home countries. They often lack trust in government and the police, because of their experiences, and this makes them reluctant to ask for help from government agencies. A barrier for organizations helping immigrants and visible minorities was described as the resource crunch faced by them in recent years due to government cutbacks.

One major priority issue participants believed should be dealt with is the issue of foreign credentials, and that it should be led by the federal government and not left to the provinces.

Mentoring was mentioned by participants as a way for visible minority and Aboriginal professionals to get help in entering the workforce. For example, people who have succeeded in breaking the barriers for themselves could mentor others wanting to break the same barriers. Being able to encourage top management of companies to make commitments to establish racism-free workplaces was seen as a high priority for success. One suggestion was that companies be required to have one visible minority or Aboriginal person on their board of directors; another was to have their representation on the sector councils set up HRSDC.

The U.S. was often praised as having gained a commitment at the national level, which participants thought was needed in Canada. Participants often stressed that the problem of racism in the workplace will not be solved without dealing with the underlying problem of racism in Canadian society. Suggestions were made to begin teaching employment equity in the public schools or even in pre-schools. Participants thought that this education should continue in the workplace.

\section{Keeping the Job Can Be Difficult}

Finding a job was seen as only the first step for visible minorities and Aboriginal people - then they have got to keep the job. One participant thought that members of the two groups were usually employed in jobs that were often short-term or temporary. Another participant talked about the "sticky floor" phenomenon, whereby people were stuck in low paying, entry-level jobs. Workplace isolation was given as a serious problem for Aboriginal employees; it was said that with few Aboriginal employees in companies, they did not feel part of the group at work.

The issue of on-the-job isolation for Aboriginal peoples could be solved by emulating the Royal Bank's Royal Eagles Program, which is designed to help its Aboriginal staff adjust to the workplace. Some people thought that managers should receive diversity training and that visible minorities and Aboriginal peoples should receive training about the dominant [workplace] culture.

Cultural and Pedagogical Inquiry, Fall 2020, 12(2), pp. 165-171

ISSN 1916-3460 @ 2020 University of Alberta

http://ejournals.library.ualberta.ca/index.php/cpi/index 
Career advancement was seen as a central issue for Aboriginal peoples and members of visible minority groups. It was said that, in time, anyone can get an entry-level job, but that advancement was significantly harder for the two groups.

Racism in the workplace was seen as a major hurdle for visible minorities and Aboriginal peoples in terms of job retention. It was suggested that they are not informed [either explicitly or implicitly] about training, promotion and secondment opportunities. Once again, lack of commitment to employment equity at the senior levels of companies is seen as key to eliminating these barriers. Lack of training and mentoring were also seen as barriers. The old boys' network was seen as a major stumbling block, because Aboriginal peoples and visible minorities are usually not invited to become members. Another barrier was seen as the difficulty in proving discrimination; people are reluctant to give evidence against their colleagues and bosses. Speaking up for one's rights was perceived as being discouraged in the workplace.

When speaking of solutions, "start at the top" was often mentioned. Participants thought that the Royal Bank set a good example, where the employment equity person reports directly to the CEO. Managers' salaries and bonuses could be tied to achieving their employment equity goals.

Although there is a high degree of uniformity in the types of barriers and proposed solutions proposed by participants across the country, there are also some variations among regions. For example, some participants thought that Halifax had a serious problem of discrimination against the black community, which has a pernicious effect on their workplace opportunities. In Montreal, many participants thought that Aboriginal peoples and visible minorities were discriminated against due to language.

The Prairie Provinces differ in many ways. One is the large presence of Aboriginal people, particularly young people leaving the reserves for urban centres. Calgary is unique in Canada, where there was more optimism, probably due to Alberta's economic boom. In Manitoba, participants thought partnerships were being tried and had proved successful in many sectors. Vancouver's special problems stem, in part, from the substantial migration of visible minorities, although it has well-established, large communities of East Indians and Chinese as well as Aboriginal people, who have the needed organizations to support themselves.

\section{The Workshops: Everyone in Learning Mode}

The workshops were used primarily for group education and training. Unlike the focus group consultations, the workshops were interactive, involving learning on both sides. Their objectives were to examine racism in the workplace; to discover how workplace policies and practices exclude people not of the majority group and to look at ways to counteract race-based employment barriers. Participants chose one of three workshops: "From politics to practice From realities to remedies;" "The business challenge: Good practices at work;" and "Implementing employment equity: A step-by-step approach."

The workshops confirmed the focus group consultations findings that participants viewed racism as integrated into the current workplace system in Canada. The old boys' network was considered by many to be imbedded in the workplace. People thought that it was the duty of managers to remedy this situation. The view was also expressed that other institutions, like the educational system, the media, police forces, municipalities and society as a whole should become engaged in

Cultural and Pedagogical Inquiry, Fall 2020, 12(2), pp. 165-171

ISSN 1916-3460 () 2020 University of Alberta

http://ejournals.library.ualberta.ca/index.php/cpi/index 
combating racism. Participants thought that, with hate crimes on the rise in Canada, now is the time to take action.

\section{Partnerships Need a Shared Vision}

The partnership sessions began with the premise that a partnership is the bringing together of different groups of people to achieve an agreed-upon goal. Participants were told that the only known partnership in the area of employment equity is in the U.S., where a consortium of state agencies called the National Alliance for Partnerships in Equity performs an advocacy role for education policy and programs to reduce bias.

A high unemployment rate for Aboriginal peoples on the Prairies was seen as a possible spur for partnership formation. This was considered particularly true, because racism in the workplace is partly responsible. Participants thought that partnerships should aim to implement training programs on career advancement and helping Aboriginal people stay in jobs. One participant thought that partnerships could launch an effort to train them about grievance procedures. This way, the problem of an uncomfortable workplace environment could be alleviated. So rather than walking away from a job, more Aboriginal people would stay on and go through the grievance procedure like other staff.

Among the challenges outlined by participants, one of the primary ones was convincing key stakeholders of the benefits to them. Many participants agreed on the conditions needed to make partnerships successful and sustainable, including shared objectives, responsibility, leadership and commitment, clear communications, trust and openness, measurable performance indicators and the availability of resources.

In terms of Canadian examples of partnerships that work well, Aboriginal Human Resources Development Agreements between the federal government and several Aboriginal groups were mentioned. One participant said that in British Columbia, five sectors have been earmarked for partnership development: tourism, energy, agriculture, forestry and the 2010 Olympics. Another participant signalled the successful partnership agreements SaskEnergy in Saskatchewan has had with the Prince Albert Grand Council, the Saskatoon Tribal Council and the Touchwood File Hills Qu'Appelle Tribal Council since the mid-1990s, providing jobs, education and training for Aboriginal people. Among visible minority groups, partnerships were forged with the City of Winnipeg, the schools and the Chamber of Commerce to set up a refugee centre, which worked well when employers were looking for agricultural labour. Other examples of successful, sustained partnerships abound across the country.

Participants thought that, for the future, partnerships should be sought with the trade sector (construction, plumbing, steam fitting and ironwork), particularly for Aboriginal people. An important suggestion was that there be partnerships among federal government departments to develop a common front to eliminate racism in the workplace. It was generally agreed that a secretariat that is cross-governmental should be put in place by the federal government. The two crucial elements needed to jump-start the racism-free workplace strategy were seen as the federal government and employers, including their umbrella organizations.

Cultural and Pedagogical Inquiry, Fall 2020, 12(2), pp. 165-171

ISSN 1916-3460 @ 2020 University of Alberta

http://ejournals.library.ualberta.ca/index.php/cpi/index 


\section{Recommendations}

The recommendations flowing from the engagement strategy are grouped under a number of headings: "the Employment Equity Act (EEA)," which includes proposals for revisions to the $E E A$, including the appointment of a commissioner, who would report annually to Parliament; and "Education, training and language," which includes the Labour Program of HRSDC taking steps to investigate Aboriginal Human Resources Development Agreements to establish how they can be used to further implement the racism-free workplace strategy.

"Foreign credentials" has a heading of its own, because the participants' agreed on the importance of the issue, and the urgent need for Canada to make the changes necessary for foreign-trained people to work in their chosen field.

Another section, called "Communication needs," proposed that Statistics Canada produce annual availability statistics for the Aboriginal peoples and members of visible minority groups. It was also recommended that the Labour Program disseminate labour market information to the two groups in the ethnic and

Aboriginal media. Another recommendation concerning communications was that CEOs of the organizations under discussion, through a mission statement or otherwise, make an unequivocal statement about what their organization believes in, which would include creating and sustaining a racism-free workplace.

"Cultural accommodation," is another section. It includes a recommendation concerning the setting aside of a quiet corner for prayer in workplaces. As well, it is recommended that one visible minority or Aboriginal person be appointed to the boards of directors of companies located in cities where 10 percent or more of the populations belong to the two groups.

In "Trade unions," recommendations identified the necessity for the Aboriginal peoples and members of visible minority groups to participate actively, as a way of influencing such policies as union hall hiring.

Finally, "Perception versus realty," recommends that employers be given a subsidy for giving newly arrived immigrants the chance to gain Canadian job experience. Another idea was that studies take place to determine ways to help improve the self-esteem of the Aboriginal peoples, after generations of institutionalization and institutionalized discrimination have fostered negative self-images.

Despite disappointment in the current workplace in Canada, most participants had a sense of hope for the future. The EEA will soon be reviewed by Parliament [2015]. They thought that change had to occur, if only due to demographics that point to a building crisis, particularly in the urban centres. 


\section{Appendix 1}

\section{Table of Contents}

Executive Summary

I Introduction

Background

Rationale for the project

Objectives

Issues

Scope of the work

Expected outcomes i.

1.

1.

2.

6.

7.

8.

8.

10.

10.

11.

12.

12.

16.

16.

31.

34.

40.

43.

46.

50.

59.

VII Recommendations 64.

\section{Appendices}

1. Summary of remarks by special invitees

2. Technical report on consultation meetings

3. Technical report on workshops

4. Technical report on partnership sessions

5. Report on the chosen cities

(In the original 2015 report, the comprehensive nature of the study (conducted in several cities across Canada) is indicated in The Table of Contents, published in its entirety as Appendix 1. John Samuel, PhD, granted permission to publish the extract from the Executive Summary, from the full report, in an email to Cecille DePass, January 14, 2020. Although the study was conducted and completed several years ago, the systemic issues identified still exist in Canada).

Cultural and Pedagogical Inquiry, Fall 2020, 12(2), pp. 165-171

ISSN 1916-3460 @ 2020 University of Alberta

http://ejournals.library.ualberta.ca/index.php/cpi/index 